\title{
Modelling transfers of carbon 14 emitted by pressurised water reactors under normal operating conditions, in continental ecosystems
}

\author{
S. Roussel-Debet, J. Garnier-Laplace, C. Mourlon' and P. Calmon' \\ Institute of Protection and Nuclear Safety, Department of Environmental Protection, \\ Laboratory of Experimental Radioecology, BP. 1, 13108 Saint-Paul-lez-Durance cedex, France \\ 1 Institute of Protection and Nuclear Safety, Department of Environmental Protection, \\ Laboratory of Environmental Modelling, BP. 1, 13108 Saint-Paul-lez-Durance cedex, France
}

\begin{abstract}
A model of transfers of ${ }^{14} \mathrm{C}$ in the terrestrial and freshwater environment, eminted by atmospheric and liquid discharges from Pressurised Water Reactors under normal operating conditions, is proposed. Despite the complexity of the ecosystems involved, a simple assessment of the transfer pathways in the environment may be envisaged on the basis of the following assumptions : (a) ${ }^{14} \mathrm{C}$ behaves like ${ }^{12} \mathrm{C}$ with an isotopic ratio between the two isotopes that is unvarying during all considered transfers, and, (b) the ${ }^{14} \mathrm{C}$ concentrations in the environment are constant over time. which is only valid for chronic discharges. This model takes into account the chemical form, mincral or organic, of the released ${ }^{14} \mathrm{C}$, and the inpul of ${ }^{14} \mathrm{C}$ through the imigation water in the case of terrestrial agricultural products. An example of human dose calculation is achieved on the basis of a standard diet, assumed to be entirely self-consumed and contaminated by a chronic discharge. In this case, the annual dose equivalent by

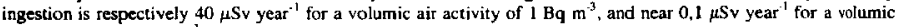
water activity of $1 \mathrm{~Bq}^{-3}$.
\end{abstract}

\section{INTRODUCTION}

Carbon has two stable isotopes: ${ }^{12} \mathrm{C}$, the most abundant, and ${ }^{13} \mathrm{C}$, about $1.1 \%$. The radioisotope ${ }^{14} \mathrm{C}$ has a half-life of $5730 \pm 40$ years and is produced naturally in the upper atmosphere $\left({ }^{14} \mathrm{~N} \stackrel{(n, p)}{\longrightarrow}{ }^{14} \mathrm{C}\right)$. In addition, there are also anthropogenic sources linked to discharges occurring during earlier atmospheric nuclear tests and to releases from fuel cycle installations and reactors.

The specific activity in a « non-contaminated " environment was reported in 1992 to be of the order of $0.260 \mathrm{~Bq} \mathrm{~g} \mathrm{~g}^{-1}[1]$.

Gaseous emissions represent an important percentage of discharges of ${ }^{14} \mathrm{C}$ from a PWR and are mainly in the form of carbon dioxide $\mathrm{CO}_{2}$, the remaining organic ${ }^{14} \mathrm{C}$, being mostly emitted as methane $\mathrm{CH}_{4}$, which plays no role in photosynthesis and is therefore not directly transferred to plants or animals.

The annual activity discharged by liquid effluents varies widely from one electronuclear site to another, and the chemical forms produced are either carbonates, or very poorly known organic compounds.

\section{BASIC MODEL CONCEPTS AND LIMITATIONS}

Carbon is, with hydrogen, oxygen, nitrogen and phosphorus, a constituent element of living matter, with a mean concentration of $44 \%$ in glucids, $50 \%$ in proteins and $76 \%$ in lipids. The behaviour in the biosphere of the radioisotope ${ }^{14} \mathrm{C}$ and its « transfer " is connected with general processes of the carbon cycle. Because these processes are particularly complex, all the models used in radioecology are based on the simplifying hypothesis of the equality of specific activities between the organism and the contaminating medium, according to the following general form :

$$
\frac{\left[{ }^{14} C\right]_{\text {organism }}}{\left[{ }^{12} C\right]_{\text {organism }}}=\frac{\left[{ }^{14} C\right]_{\text {mediwm }}}{\left[{ }^{12} C\right]_{\text {medium }}}
$$


with $\left[{ }^{14} \mathrm{C}\right]_{\text {medium }}$, the volumic activity of ${ }^{14} \mathrm{C}$ in the medium $\left.\left(\mathrm{Bq} \mathrm{m}^{-3}\right), \mathrm{l}^{12} \mathrm{C}\right]_{\text {medium }}$, the concentration of ${ }^{12} \mathrm{C}$ in the medium $\left(\mathrm{kg} \mathrm{m}^{-3}\right),\left[{ }^{14} \mathrm{C}\right]_{\text {organism }}$, the mass or volumic activity of ${ }^{14} \mathrm{C}$ in the plant or animal organism considered ( $\mathrm{Bq} \mathrm{kg}{ }^{-1} \mathrm{w} . \mathrm{w}$.) and $\left[{ }^{12} \mathrm{C}\right]_{\text {erginism }}$, the concentration of ${ }^{12} \mathrm{C}$ in the organism $\left(\mathrm{kg} \mathrm{kg}^{-1} \mathrm{w}\right.$. w.).

The uptake of carbon in the human organism is essentially linked to ingestion, at a rate of about $300 \mathrm{~g}$ a day for an adult, almost entirely absorbed, as opposed to $3 \mathrm{~g}$ a day of carbon inhaled, of which only $1 \%$ is fixed in the organism [2].

\section{3. ${ }^{14} \mathrm{C}$ TRANSFER IN FRESHWATER ECOSYSTEMS}

\subsection{Transfer to the primary production compartment}

${ }^{14} \mathrm{C}$ mineral forms are incorporated by the way of photosynthesis achieved by primary production (phytoplankton and macrophyta biomass). The mineral ${ }^{14} \mathrm{C}$ transfer model can be envisaged in highly simplified form on the basis of the equation (1), with the conservative assumption that the organism spends its whole life under chronic contamination conditions, so:

$$
\left[{ }^{14} C\right]_{0}=\frac{\left[{ }^{14} C_{\text {min }}\right]_{\text {wase }}}{\left[{ }^{12} C_{\text {min }}\right]_{\text {warer }}} f_{n_{0}}
$$

with, $\left[{ }^{14} \mathrm{C}\right\rfloor_{0}$, the ${ }^{14} \mathrm{C}$ concentration in the organism or in the population of the " $n_{0}$ " trophic level $\left(\mathrm{Bq} \mathrm{kg}^{-1}\right.$ w. w.), $\left[{ }^{12} \mathrm{C}_{\min }\right]_{\text {rater }}$, the total mineral carbon concentration in the water $\left(\mathrm{g} \mathrm{l}^{-1}\right),\left[{ }^{14} \mathrm{C} \text { min }\right]_{\text {ater }}$, the total mineral ${ }^{14} \mathrm{C}$ concentration in the water added to the water course $\left(\mathrm{Bq} \mathrm{l} \mathrm{l}^{-1}\right)$ and $f_{r_{n_{0}}}$, the ${ }^{12} \mathrm{C}\left(\mathrm{kg} \mathrm{kg}^{-1} \mathrm{~W}\right.$. w.) concentration in the organism.

For semi aquatic macrophyta, equation (3) has to be complicated to take into account immerged parts of the plant and transfer from atmospheric compartment for aerial parts. Assuming a constant value for the $\mathrm{C}$ proportion for the two part of the plant, the ${ }^{14} \mathrm{C}$ concentration in such organism can be estimated by the following equation to avoid overestimation with the hypothesis of additivity of the two transfer pathways:

$$
\left[{ }^{14} C\right]_{h o}=f c_{n_{0}} . \operatorname{Max}\left(\frac{\left[{ }^{14} C_{\text {min }}\right]_{\text {water }}}{\left[{ }^{12} C_{\text {min }}\right]_{\text {water }}}, \frac{\left[{ }^{14} C\right]_{\text {hir }}}{\left[{ }^{12} C\right]_{h a r}}\right)
$$

\subsection{Transfer to animals of different trophic levels}

For the successive consumers, at trophic level $n_{j}(j>0)$, the same type of formulation may be used, considering direct transfer (osmoregulation or respiration) is negligible in comparison to trophic transfer (ingestion of preys of the $(j-1)$ trophic level) :

$$
\left[{ }^{14} C\right]_{h_{j}}=\frac{f_{n_{n_{j}}}}{f_{c_{n_{j-1}}}}\left[{ }^{14} C\right]_{,-1}
$$

where $f_{n_{j}}$ or $f_{n_{j-1}}$ represents the ${ }^{12} \mathrm{C}$ concentration in the organism at trophic level $n_{j}$ or $n_{j-l}$ respectively (kg kg ${ }^{-1}$ w. w.).

Moreover, ${ }^{14} \mathrm{C}$ organic forms can be incorporated from the first order trophic level, using, first the same formulation as used in equation (2) with the isotopic ratio concerning organic forms, and then, equation (4) to calculate the transfer to higher trophic levels.

The very slow kinetic of mineralisation of organic carbon and the constant renewal of water in a river allow not to consider this ${ }^{14} \mathrm{C}$ transformation in the close field of the discharge point. Finally, at 
equilibrium, mineral forms of ${ }^{14} \mathrm{C}$ in the water of the receptor river come from the PWR's liquid effluent releases with only a part that has been consumed by photosynthesis. Then, the expression $\left[{ }^{14} \mathrm{C} \text { min }\right]_{\text {wure }}=p_{m_{\text {water }}} \cdot\left[{ }^{14} \mathrm{C}\right]_{\text {wrer }}$ can be considered as an overestimation.

For the organic forms of ${ }^{14} \mathrm{C}$ in the river water, the expression $\left[{ }^{14} \mathrm{Corg}\right]_{\text {ater }}=\left(1-p_{m_{\text {water }}}\right) \cdot\left[{ }^{14} \mathrm{C}\right]_{\text {hater }}$ is retained as first approximation.

Finally, for fish of different trophic leveis likely to be ingested by man, a first estimation, reasonably conservative, can be proposed to take into account both organic and mineral forms of released ${ }^{14} \mathrm{C}$ as follows :

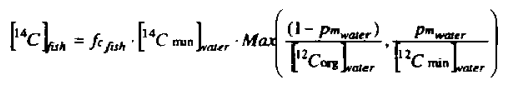

with, $\left(1-p_{m_{\text {water }}}\right)$, the proportion of ${ }^{14} \mathrm{C}$ released as organic forms, $p_{m_{\text {warer }}}$, the proportion of ${ }^{14} \mathrm{C}$ released as mineral forms, $f_{f_{\text {fish }}}$ the carbon content of the fish $\left(\mathrm{kg} \mathrm{kg}^{-1} \mathrm{w} . \mathrm{w}\right.$.) and, $\left[{ }^{14} C_{\text {min }}\right]_{\text {water }}$, the ${ }^{14} \mathrm{C}$ total concentration for mineral forms in water $\left(\mathrm{Bq} \mathrm{l} \mathrm{l}^{-1}\right)$. We propose a value of $0.050 \mathrm{~kg} \mathrm{C} \mathrm{kg}^{-1} \mathrm{w}$. w. for $f_{c_{\text {frsh }}}$.

\section{4. ${ }^{14} \mathrm{C}$ TRANSFER IN TERRESTRIAL ECOSYSTEMS : VEGETAL AND ANIMAL FOODSTUFFS}

\subsection{Direct transfer from the atmosphere to plants}

It is assumed that all the carbon taken up by plants comes from the atmosphere and that the mineral form intervenes only at local level (assumed to be in the form of $\mathrm{CO}_{2}$ ). The activity of ${ }^{14} \mathrm{C}$ in plants is estimated by :

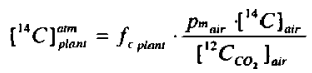

with $f_{\text {c plant }}$, the proportion of stable carbon of the plant considered $\left(\mathrm{kg} \mathrm{kg}^{-1} \mathrm{w} . \mathrm{w}\right.$.), $p_{\text {marr }}$, the proportion of ${ }^{14} \mathrm{C}$ discharged in mineral form in the air, $\left[{ }^{12} \mathrm{C}_{\mathrm{CO}_{2}}\right]_{\text {air }}$, the atmospheric concentration of stable carbon in the form of $\mathrm{CO}_{2}\left(\mathrm{~kg} \mathrm{~m}^{-3}\right)$ and $\left[{ }^{14} \mathrm{C}_{\text {air }}\right.$, the atmospheric concentration of ${ }^{14} \mathrm{C}\left(\mathrm{Bq} \mathrm{m}^{-3}\right)$. The atmospheric concentration in stable carbon in the form of $\mathrm{CO}_{2}$ is taken as $0.19 \times 10^{-3} \mathrm{~kg} \mathrm{~m}^{-3}$. The default values for $f_{\text {c pleas }}$, are indicated in Table 1. 
Table 1 : Default values for the carbon fraction of plants and animal origin products, according to NCRP [3].

\begin{tabular}{|c|c|}
\hline Product $k$ & $f_{\mathrm{rk}}$ \\
\hline Leaf vegetables & 0.035 \\
\hline Other vegetable & 0.072 \\
\hline Fruit & 0.065 \\
\hline Cereals & 0.360 \\
\hline Fresh milk and milk products & 0.067 \\
\hline Butter & 0.620 \\
\hline Cheese & 0.350 \\
\hline Egros & 0.156 \\
\hline Beef & 0.228 \\
\hline Pork & 0.402 \\
\hline Chicken & 0.156 \\
\hline Mutton & 0.289 \\
\hline
\end{tabular}

\subsection{Indirect transfer from irrigated land to plants}

It is assumed that the mass plant activity coming from soil emanation $\left[{ }^{14} C\right]_{\text {plant }}^{\text {sol }}\left(\mathrm{Bq}_{\mathrm{kg}}{ }^{-1}\right.$ w. w. $)$ is proportional to the ratio $\varphi^{12} \mathrm{C}\left(\mathrm{kg} \mathrm{m}^{-2}\right.$ year $\left.^{-1}\right) / \varphi^{10} \mathrm{C}\left(\mathrm{Bq} \mathrm{m}^{-2}\right.$ year $\left.{ }^{-1}\right)$ of $\mathrm{CO}_{2}$ flux emanating from the soil and to $\left[^{12} C\right]_{\text {plant }}^{\text {sot }}$, the concentration of the plant in ${ }^{12} \mathrm{C}\left(\mathrm{kg} \mathrm{kg}^{-1}\right.$ w.w.), i.e. $\left[{ }^{14} \mathrm{C}\right]_{\text {ptant }}^{\text {solt }}=\left[{ }^{12} \mathrm{C}\right]_{\text {plant }}^{\text {soil }} \frac{\varphi^{11} \mathrm{C}}{\varphi^{12} \mathrm{C}}$. The ${ }^{12} \mathrm{C}$ concentration of the plant derived from the $\mathrm{CO}_{2}$ released by the soil $\left[{ }^{12} \mathrm{C}\right]_{\text {plant }}^{\text {soll }}$ is equal to the product of the proportion of ${ }^{12} \mathrm{C}$ of the plant $f_{c \text { plans }}$ by the fraction $f$ of this carbon concentration resulting from the uptake of emanated $\mathrm{CO}_{2}$, or, $\left[{ }^{14} \mathrm{C}\right]_{\text {pland }}^{\text {soit }}=\frac{\varphi^{14} \mathrm{C}}{\varphi^{12} \mathrm{C}} \cdot f \cdot f_{c_{\text {plant }}}$. Upon the hypothesis that the ${ }^{14} \mathrm{C}$ emanated flux derives from the whole amount of the ${ }^{14} \mathrm{C}$ input from irrigation, in both mineral and organic form, this flux $\varphi^{1 "}{ }^{\prime C}\left(\mathrm{~Bq} \mathrm{~m}^{-2}\right.$ year $\left.{ }^{-1}\right)$ is equal to the product of the amount of the irrigation water $T_{\text {water }}\left(\mathrm{m}^{3} \mathrm{~m}^{-2}\right.$ year $\left.{ }^{-1}\right)$ by the volumic activity of the irrigation water $\left[{ }^{14} \mathrm{C}_{\text {warer }}\left(\mathrm{Bq} \mathrm{m}^{-3}\right)\right.$, whence :

$$
\left[^{14} C\right]_{\text {piant }}^{\text {soil }}=\frac{T_{\text {water }}\left[{ }^{14} C\right]_{\text {warr }}}{\varphi^{10} C} \cdot f \cdot f_{\text {plant }}
$$

The values for $f_{r \text { pirst }}$ are indicated in Table $1 ;$ the value for $\varphi^{12} c$ is estimated on average $5 \mathrm{~g} \mathrm{~m}^{-2} \mathrm{~d}^{-1}$ $\left(0.498 \mathrm{~kg} \mathrm{C} \mathrm{m}^{-2} \mathrm{y}^{-1}\right)$ for cultivated ground, although up to 5 times higher values can be encountered under dense cultures [4] [5]. The fraction of carbon released from the ground participating in photosynthesis $f$ is of the order of $20 \%[6]$. The rate of irrigation $T_{\text {water }}$ depends on the region and the type of culture ; by default, the mean order of size is $0.5 \mathrm{~m}^{3} \mathrm{~m}^{2}$ year ${ }^{-1}$. This parameter, which may be null or may vary considerably, should be adjusted for each site and for each type of culture.

\subsection{Simultaneous liquid and atmospheric releases}

When gaseous and liquid releases occur simultaneously, the simple addition of transfer due to atmospheric and liquid pathways would unrealistically overestimate the total carbon incorporation, which is finally controlled by the carbon budget of the plant itself. Thus, the total ${ }^{14} \mathrm{C}$ activity in the vegetal should be estimated by :

$$
\left[{ }^{14} C\right]_{\text {plant }}=\left[\frac{(1-f) \cdot p_{m_{\text {air }}} \cdot\left[{ }^{14} C\right]_{\text {air }}}{\left[{ }^{12} C_{\mathrm{CO}_{2}}\right]_{\text {air }}}+\frac{f \cdot T_{\text {water }} \cdot\left[{ }^{14} C\right]_{\text {winker }}}{\varphi^{12} C}\right] \cdot f_{c_{p l a w}}
$$


More than $99 \%$ of the carbon uptake by bred animals comes from the ingestion of the foods that make up the daily ration: inputs of carbon from the ingestion of water or from the ground are negligible [7]. Assuming that the animal's food ration is contaminated with ${ }^{14} \mathrm{C}$ (no exogenous input), calculation of the specific activity of carbon in products of animal origin is done on the basis of that of plants by applying the equation (1). Since plants are contaminated by atmospheric or liquid pathways, the ${ }^{14} \mathrm{C}$ activity in the products $k$ of animal is respectively:

and,

$$
\left[{ }^{14} C\right]_{k}^{a m m}=\frac{f_{c_{k}}}{\left[{ }^{12} C_{C O_{1}}\right]_{a i r}} \cdot p m_{\text {air }}\left[f^{14} C\right]_{a r r}
$$

$$
\left.\left[^{14} C\right]_{k}^{l m}=\frac{T_{\text {water }}}{\varphi} \cdot f \cdot f_{r_{k}} l^{14} C\right]_{\text {water }}
$$

When both liquid and atmospheric pathways occur, the products $k$ of animal origin combine the respective contributions of these pathways :

$$
\left.I^{14} C\right]_{k}=\left[\frac{(1-f) \cdot p_{m_{\text {arr }}} \cdot\left[{ }^{14} C\right]_{\text {air }}}{\left[{ }^{12} C_{C O_{2}}\right]_{\text {air }}}+\frac{f \cdot T_{\text {water }} \cdot\left[{ }^{14} C\right]_{\text {mater }}}{\phi^{12} \mathrm{C}}\right] \cdot f_{c_{t}}
$$

\section{NUMERICAL APPLICATION}

The formulations described above are illustrated by a numerical application taking into account mean unitary concentrations of ${ }^{14} \mathrm{C}$ in freshwater and in the air i.e. $I^{14} \mathrm{C} J_{\text {wair }}=1 \mathrm{~Bq} \mathrm{~m} \mathrm{~m}^{-3}$ and $\left.l^{14} \mathrm{C}\right]_{\text {air }}=1 \mathrm{~Bq} \mathrm{~m} \mathrm{~m}^{-3}$, which is only a scenario for calculation purposes, according to the fact that liquid and gazeous release rates would not actually lead to the same concentrations in the receptor mediums, water and air. The proportion of mineral carbon in atmospheric discharge is assumed to be equal to 0.2 whereas the carbon of the liquid discharge is assumed to be entirely in mineral form. In freshwater, carbon concentration is taken to be equal to $10 \mathrm{mg} \mathrm{Cl}^{-1}$ for the mineral form. The biosphere considered corresponds to a hypothetical French site where inhabitants derive all their foodstuffs, freshwater fish, vegetation and animal products, from a large steady state contaminated area. Plants are supposed to be irrigated with river water at a rate of $0.5 \mathrm{~m}^{3} \mathrm{~m}^{-2} \mathrm{y}^{-1}$. The mean values for consumption by adult man adopted for this example have been established on the basis of the report by Quinault et al [8] and may be overestimated: some foods are not in fact produced in proximity to the nuclear plants considered or do not come from irrigated zones. The effective dose factor by ingestion is taken as $5.8 \times 10^{-10} \mathrm{~Sv} \mathrm{~Bq}^{-1}$ for the adult [9]. Under these conditions, the effective dose equivalent is $40 \mu \mathrm{Sv}$ year ${ }^{-1}$ per Bq $\mathrm{m}^{-3}$ for the atmospheric pathway and $0.097 \mu \mathrm{Sv}$ year ${ }^{-1}$ per $\mathrm{Bq} \mathrm{m^{-3 }}$ for the liquid pathway. The contribution of the various foodstuffs to this dose is : plants $47 \%$ (including $29 \%$ for the cereals), dairy produce and eggs $32 \%$, meat $21 \%$ for the atmospheric discharges, and, for the liquid discharges : fish $91 \%$. These values vary according to the food ration considered and according to the various hypotheses that have been described.

\section{CONCLUSION}

The proposed model for assessing the transfer in the environment, in the vicinity of the site, of ${ }^{14} \mathrm{C}$ emitted by PWRs under normal operating conditions aims to be more representative of the processes involved in the carbon cycle than the models generally presented in the literature. In particular, the utilisation of local parameters should make possible calculations of human doses that are better suited to the site studied, than default values proposed for these parameters. 
The present study points out certain data that are lacking for the study of the fate of carbon in the environment, starting with the composition (nature and proportion) of carbon compounds discharged in liquid effluents. A better knowledge of the carbon cycle would also appear to be necessary, both at large scale (air-water exchanges, sea-land exchanges in spray, the taking into account of sediments as secondary source term in aquatic environment, etc.) and at small scale (determination of the kinetics of transformations of organic and mineral carbon and uptake of carbon in specific organic form by living organisms).

The proposed transfer model can only be used at equilibrium on the basis of the hypothesis of equality of specific activities between compartments, and offers the means to analyse a situation of chronic discharge defined by a constant concentration of ${ }^{14} \mathrm{C}$ in the receptor compartments, for the period studied. In the absence of existing information, the proposed model does not take into account the possibilities of isotopic fractionating of the carbon.

At present, there is no suitable model enabling estimation of the fate in the environment of occasional discharge of ${ }^{14} \mathrm{C}$, for which the hypothesis of conservation of isotopic ratios is unsuited.

\section{Acknowledgments}

The authors acknowledge the financial support received from ÉLECTRICITÉ DE FraNCE, Service Études et Projets Thermiques et Nucléaires.

\section{References}

[1] Otlet, R.L., Walker, A. J., Fulker, M. J., \& Collins, C.(1997) . Background Carbon - 14 levels in UK foodstuffs, 1981 - 1995, based upon a 1992 Survey. Joumal of Environmental Radioactivity, 34, 91 101.

[2] ICRP (1974). Report of the task group on Reference Man. International Commission on Radiological Protection $n^{\circ} 23$. Vienne : ICRP.

[3] NCRP (1984). Radiological assessment : predicting the transport, bioaccumulation and uptake by man of radionuclides released to the environment." NCRP Report $\mathrm{N}^{\circ} 76$. Bethesda : NCRP.

[4] Hénin, S. (1976). Cours de physique du sol, Orstom. Initiations. Report $\mathrm{N}^{\circ} 28$, Paris : Documentations techniques.

[5] Rayment, M. B. (2000). Closed chamber systems underestimate soil $\mathrm{CO}_{2}$ efflux. European journal of soil science, 51, 107-110.

[6] Belot, Y. (1991). Comportement du carbone-14 provenant de matériaux enfouis a faible profondeur dans le sol. Rapport IPSN/DPRE/SERGD91/15, Fontenay-aux-Roses : IPSN.

[7] Garnier-Laplace, J., Roussel-Debet, S., \& Calmon, Ph. (1998). Modélisation des transferts du carbone 14 émis par les réacteurs à eau pressurisée en fonctionnement normal, dans l'environnement proche du site. Rapport IPSN/DPRE/SERE/98/007, Cadarache : IPSN.

[8] Quinault, J.M., Cartier, Y., Bourdeau, F., Beaugelin-Seiller, K., \& Mourlon, C. (1999). Guide d'évaluation de l'impact de rejets radioatifs atmosphériques. Rapport IPSN/DPRE/SERLAB 99/011, Cadarache : IPSN.

[9] ICRP. (1996). Age-dependent doses to members of the public from intake of radionuclides : part 5. Compilation of ingestion and inhalation dose coefficients. Publication $\mathrm{n}^{\circ} 72$, annals of the ICRP, 26. Vienne : ICRP. 